\title{
The Screening of Antimicrobial Bacteria with Diverse Novel Nonribosomal Peptide Synthetase (NRPS) Genes from South China Sea Sponges
}

\author{
Wei Zhang $\cdot$ Zhiyong Li $\cdot$ Xiaoling Miao $\cdot$ Fengli Zhang
}

Published online: 10 February 2009

(C) Springer Science + Business Media, LLC 2009

\section{Erratum to: Mar Biotechnol \\ DOI 10.1007/s10126-008-9148-z}

In the original version of this article, there has been an error in second sentence of the first paragraph of "NRPS Genes Screening and Phylogenetic Analysis", in Materials and Methods section. The sentence should read:

PCR was performed using the following amplification parameters: initial denaturation at $94^{\circ} \mathrm{C}$ for $5 \mathrm{~min}$, then 35 cycles of $94^{\circ} \mathrm{C}$ for $1 \mathrm{~min}$, annealing at $55^{\circ} \mathrm{C}$ for $1 \mathrm{~min}$, extension at $72^{\circ} \mathrm{C}$ for $2 \mathrm{~min}$, and a final extension at $72^{\circ} \mathrm{C}$ for $10 \mathrm{~min}$.

The online version of the original article can be found at http://dx.doi. org/10.1007/s10126-008-9148-z.

W. Zhang $\cdot$ Z. Li $\cdot$ X. Miao $\cdot$ F. Zhang

Laboratory of Marine Biotechnology and Key Laboratory of

Microbial Metabolism, Ministry of Education,

School of Life Science and Biotechnology,

Shanghai Jiao Tong University,

Shanghai 200240, People's Republic of China

Z. Li $(\bowtie)$

School of Life Science and Biotechnology,

Shanghai Jiao Tong University,

800 Dongchuan Road,

Shanghai 200240, People's Republic of China

e-mail: zyli@sjtu.edu.cn 